\title{
PERMAINAN TRADISIONAL SEBAGAI MODEL PERMAINAN EDUKATIF UNTUK MENINGKATKAN KEMAMPUAN SOSIAL EMOSIONAL ANAK USIA DINI
}

\author{
Yusria $^{1}$, Khalid Musyaddad ${ }^{2}$ \\ ${ }^{1,2}$ Universitas Islam Negeri Sulthan Thaha Saifuddin Jambi \\ 1yusria@uinjambi.ac.id
}

\begin{abstract}
This study aims to develop one of the traditional educational game model in early childhood. This research method uses 9 steps from steps described by Borg and Gall, namely: (1) data research and, (2) planning, (3) initial product development, (4) initial trial, (5) initial improvement, (6) field trial, (7) operasional improvement, (8) evaluation product through expert validity, and (9) improvement. This study uses 3 stages, try, the first was conducted at RA Ibnu Sina with a total of 10 childrens. While the another trial was applied in RA Nurul Islam and Al-Jauharen with respondent as many as 20 childrents. In this study it was stated that the application of traditional congklak game models can effectively improve the social emotional abilities of early childhood. As well as thought traditional congklak games can help children develop various aspects of development as a whole and integrated to become more skilled and capable.
\end{abstract}

Keywords: AUD:improvement of social emotionalabilities; traditional game.

\begin{abstract}
Abstrak
Penelitian ini bertujuan untuk mengembangkan salah satu permainan tradisional menjadi model permainan tradisional edukatif pada anak usia dini. Metode penelitian ini menggunakan 9 langkah dari 10 langkah yang telah diuraikan oleh Borg and Gall yaitu: (1) penelitian dan pengumplan data, (2) perencanaan, (3) pengembangan produk awal, (4) uji coba awal, (5) perbaikan awal, (6) uuji coba lapangan 1, (7) pernaikan operasional, (8) evaluasi terhadap prodk melalui validitas pakar, dan (9) perbaikan. Penelitian ini menggunakan 3 tahap ji coba, uji coba pertama dilakukan di RA Ibnu Sina dengan jumlah responden sebanyak 10 anak. Sedangkan uji coba lainnya diterapkan di RA Nurul Islam dan Al-Jauharen dengan responden sebanyak 20 anak. Pada penelitian ini dinyatakan bahwa penerapan model permainan tradisional congklak secara efektif dapat meningkatkan kemampuan sosial emosional anak usia dini. Serta melalui permainan tradisional congklak dapat membantu anak mengembangkan berbagai aspek perkembangan secara menyeluruh dan terpadu untuk menjadi lebih terampil dan cakap.
\end{abstract}

Kata Kunci:AUD;peningkatan kemampuan sosial emosional; permainan tradisional.

\section{PENDAHULUAN}

Pendidikan memberikan pengaruh yang besar dalam kehidupan suatu bangsa, salah satu yang dapat dilakukan yaitu meningkatkan perkembangan pendidikan (Rodiawati, 2018), karena semakin tinggi kualitas pendidikan suatu Negara, maka kualitas SDM Negara tersebut semakin tinggi. Karena kualitas SDM yang tinggi akan 
meningkatkan kesejahteraan masyarakat (Karyanti \& Komarudin, 2017). Pendidikan sendiri mempunyai peranan penting dalam menciptakan suatu individu yang berkualitas (Widyawati, 2016). Pendidikan anak usia dini (PAUD) merupakan pendidikan yang ditujuan kepada anak usia dini untuk untuk merangsang perkembangan anak untuk persiapan memasuki pendidikan lebih lanjut (Munawaroh, 2017).

Perkembangan didefinisikan sebagai tugas yang timbul pada atau sekitar periode kehidupan individu tertentu, keberhasilan melakukannya menimbulkan kebahagian dan keberhasilan pelaksanaan tugas selanjutnya kelak, sedangkan kegagalan menimbulkan ketidak bahagiaan, ketidak setujuan masyarakat, dan kesulitan dalam pelaksanaan tugas lainnya kelak (Harloch., 1978). Dipahami bahwa anak usia dini harus mampu memenuhi tuntutan perkembangan untuk menghadapi persoalan di masa yang akan datang, sedangkan aktivitas anak yang dilakukan sepanjang hari adalah bermain. Sesungguhnya bermain yang dilakukan anak dapat melatih anak untuk berkonsentrasi, dengan berkonsentrasi dapat mengantarkan anak mencapai kemampuan maksimal ketika terfokus pada kegiatan bermain dan bereksplorasi dengan bermain. Sehingga dapat disimpulkan bahwa bermain adalah pekerjaan anak (Santrock, 2012).

Ketika anak sedang bermain, interaksi sosial terjalin dapat menguntungkan kemampuan literasi sehingga pertumbuhan fisik pun menjadi maksimal (Prisia Yudiwinata, 2014). Waktu bermain yang lebih lama mendorong anak untuk terlibat dalam bentuk bermain kognitif dan sosial yang lebih tinggi, karena dengan alokasi waktu yang panjang, anak berkemungkinan mengajak anak-anak lain dan bernegosiasi untuk bermain sosiodrama. Managemen waktu yang seperti ini dapat meningkatkan secara umum bermain kelompok tersebut yang mengharuskan para pemain terlibat dalam komunikasi verbal yang ekstensif dan intensif (Christie, 1990).

Sebelum permainan-permainan modern saat ini berkembang pesat, dahulu anakanak pada zamannya sangat menggemari permainan tradisional seperti petak umpet, lompat tali, kelereng, gangsing, congklak, dan lain sebagainya. Namun seiring dengan perkembangan zaman yang begitu pesat saat ini, dimana kemajuan ilmu pengetahuan dan ilmu teknologi membuat permainan tradisional mulai dilupakan (Syaodih, 2013). Padahal sebenarnya permainan modern hampir kurang mengembangkan kemampuan sosial dan interaksi anak satu dengan yang lainnya, bahkan lebih cenderung banyak mengarahkan gejolak emosional yang kurang terkontrol pada anak. Disisi lain salah satu 
dampak yang terjadi akibat permainan modern yaitu menimbulkan masalah terhadap perkembangan sosial emosional anak diantaranya seperti anak ingin menang sendiri, memilih-milih teman dan ketidakmampuan anak untuk menyesuaikan lingkungan baru (Nurihsan, 2013).

Penelitian sebelumnya telah dilakukan mengenai model permainan tradisional, pada penelitian Hapidin dan Yenina menyimpulkan bahwa pengembangan model permainan tradisional menjadi permainan tradisional edukatif secara efektif dengan meningkatkan karakter positif pada anak usia dini, dan melalui pengalaman interaksional anak saling mempelajari berbagai pengetahuan, nilai sikap dan peilaku (Hapidin \& Yenina, 2016). Kemudian pada penelitian Hikmah dan Pambudi menyimpulkan bahwa dengan anak-anak melakukan permainan tradisional, maka dapat lebih mengembangkan kemampuan dan karakternya (Prisia Yudiwinata, 2014).

Perbedaan antara penelitian ini dengan penelitian sebelumnya yaitu terletak pada model permainan tradisional yang digunakan dan banyaknya permainan. Hal yang membedakan lainnya yaitu subjek penelitian yang diambil, jika pada penelitian sebelumnya pada subjek anak sekolah dasar, maka penelitian ini akan dilakukan pada anak usia dini.

Melihat kondisi dan interaksi sosial emosional anak usia dini saat ini berkenaan dengan pengaruh permainan tradisional terhadap perkembangan anak, maka penulis melakuka kajian melalui pengembangan model permainan tradisional yang dapat menjadi salah satu bentuk kearifan lokal, dan juga untuk mengembangkan kemampuan sosial emosional pada anak usia dini. Penelitian ini berfokus pada pengembangan permainan tradisional yang mengembangkan kemampuan sosial emosional anak yaitu permainan tradisional congklak dan ular naga.

\section{METODE PENELITIAN}

Jenis penelitian yang digunakan yaitu penelitian dan pengembangan atau dalam bahasa inggris disebuat dengan Research and Development (R\&D). Metode ini dipilih karena sasaran dan tujuan akhir penelitian ini bertujuan untuk menemukan dan mengembangkan model penelitian tradisional menjadi model permainan tradisonal edukatif untuk dapat digunakan sebagai alternatif metode pembelajaran.langkah model pengembangan mencakup 9 langkah dari 10 langkah yang ada sebagaimana telah 
diuraikan oleh Borg and Gall, yaitu: (1) penelitian dan pengumpulan data, (2) perencanaan, (3) pengembangan produk awal, (4) uji coba awal, (5) perbaikan awal, (6) uji coba lapangan, (7) perbaikan operasional, (8) evaluasi terhadap produk melalui validitas pakar, (9) perbaikan.

Uji coba penelitian ini akan dilakukan di tiga Raudhatul Athfal (RA), uji coba petama dilakukan di RA Ibnu sina dengan jumlah responden sebanyak 10 anak. Kemudian uji coba lapangan dan efektifitas dilakukan di RA Nurul Islamm dan AlJauharen dengan masing-masing responden sebanyak 10 anak.

\section{HASIL PENELITIAN DAN PEMBAHASAN}

\section{Penelitian dan Pengumpulan Data}

Berdasarkan hasil survei peneliti, dari ketiga RA dua diantaranya yaitu RA Ibnu Sina dan Nurul Islam telah menerapkan permainan tradisional seperti lompat tali, kelereng, petak umpeet, namun untuk permainan tradisional tersebut hanya sekedar dimainkan. Hasil wawancara peneliti dengan guru, para guru belum mengetahui nilai dan makna apa yang dapat diperoleh dari permainan tersebut. Seperti permainan congklak dan ular naga tidak pernah dimainkan di sekolah, namun anak-anak mengenal permainan tersebut dan sebagian dari mereka pernah memainkannya di lingkungan tempat tinggal mereka.

Berdasarkan pengamatan terhadap anak-anak diketahui banyak aspek sosial emosional anak yang menjadi perhatian. Guru hanya memperhatikan aspek akademikkognitif, mereka mengabaikan aspek sosial emosional pada anak. Guru mengajar secara formal, hal tersebut didasari karena apabila guru menggunakan metode bermain, orang tua anak beranggapan anak mereka tidak belajar. Kenyatannya, memang benar saat penelitian ini berlangsung orang tua lebih menuntut anak mereka untuk belajar seperti membaca, menulis, dan berhitung.

\section{Perencanaan}

Pada penelitian permainan tradisional yang akan diterapkan yaitu permainan congklak dan ular naga. Secara historis permainan congklak adalah permainan tradisional yang diwariskan khususnya bagi anak perempuan. Sementara permainan ular naga sebagai salah satu permainan yang mengakomodir untuk dimainkan anak laki-laki 
maupun anak perempuan. Namun, dalam penelitian ini, diharapkan untuk permainan congklak dan ular naga dapat dimainkan bagi anak perempuan dan laki-laki.

Melalui permainan tradisional yang diterapkan perkembangan yang dapat dikembangkan yaitu perkembangan kognitif, bahasa, motorik, dan sosial emosional. Prinsip pembelajaran anak usi dini holistik, integratif dan menyenangkan dapat diterapkan menggunakan metode belajar sambil bermain dengan model permainan congklak dan ular naga sesuai dengan kurikulum yang digunakan. Dalam penelitian yang akan dilakukan nantinya akan dibentuk kelompok anak, dimana dalam 1 kelompok akan terdiri dari 2 orang anak yang saling berpasangan. Ketika salah satu kelompok bermain, maka kelompok lainnya menunggu giliran bermain dengan cara memainkan permainan ular naga.

\section{Pengembangan produk}

Model permainan congklak untuk anak usia 5-6 tahun, langkah-langkah yang dapat dilakukan yaitu sebagai berikut: (1) menyiapkan papan media congklak yang terdiri dari 14 ubang dan ditambah dengan 2 lubang penyimpanan yang tersedia di ujung kanan dan ujung kri, (2) biji congklak sebagai media untuk bermain berjumlah 98 buah, (3) permainan congklak terdiri dari 2 orang pemain, (4) pemain memasukkan biji-biji congklak ke dalam lubang masing-masing, setiap lubang terdiri dari 7 biji congklak, (5) sebelum permainan dimulai kedua pemain melakukan suit untuk menentukan siapa yang bermain lebih dulu, (6) pemain yang menang suit maka ia bermain lebih dulu, (7) pemain yang sedang bermain harus mengisi seluruh seluruh lubang dengan biji congkalk satu per satu dengan jumlah yang sama secara berurutan sesuai dengan arah jarum jam, (8) lubang penyimpanan hanya diisi oleh pemain bersangkutan yang sedang bermain, (9) pemain yang sedang bermain akan berakhir bermain jika biji congklak terakhir dimasukkan ke dalam lubang yang kosong, (10) permainan akan berakhir jika seluruh biji telah dimasukkan ke dalam lubang penyimpanan, (11) kedua pemain menghitung jumlah biji congklak yang terdapat pada lubang penyimpanan masingmasing, (12) salah satu pemain dinyatakan sebagai pemenang apabila biji congklaknya lebih banyak dibandingkan dengan lawan main.

Sebelum permainan dimulai, anak-anak yang bermain diberi penjelasan tentang aturan-aturan bermain yang harus disepakati dan dipatuhi. Aturan-aturan tersebut yaitu: 
(1) pemain harus suit sebelum mulai bermain, (2) pemain tidak diperbolehkan berjalanjalan, (3) pemain tidak diperbolehkan mengganggu teman lainnya, (4) durasi permainan selama 30-60 menit, (5) pemain yang melanggar aturan, maka akan didiskualifikasi dari permainan. Banyaknya alat permainan congklak pada uji coba yaitu sebanyak 3 buah congkah, dimana dalam 1 kelompok akan menggunakan 1 buah congklak.

\section{Uji Coba Awal}

Uji coba awal model permainan congklak dilakukan pada tanggal 23, 24, dan 32 Maret dan 6 April 2018 di RA Ibnu Sina di Kelurahan Ulu Gedong Kecamatan Olak Kemang Jambi Kota Seberang. Subjek uji coba yaitu kelompok belajar anak usia 5-6 tahun yang berjumlah 10 anak. Pada awal model permainan menggunakan 2 model permainan yaitu congklak dan ular naga. Berdasarkan hasil pengamatan saat model permainan ular naga kurang menarik bagi anak-anak untuk melakukannya. Setelah diamati penyebab kurang minat anak untuk bermain ular naga yaitu permainan ular naga tidak menggunakan media permainan lain kecuali diri anak itu sendiri. Sehingga, saat permainan ular naga dilakukan anak kurang meminati, dan ketika guru mengajak untuk bermain pada putaran kedua, anak-anak tidak lagi kembali pada permainan ular naga. Namun mereka meninggalkan permainan ular naga tersebut.

Permainan ular naga akhirnya berakhir dan berpindah untuk memainkan model permainan congklak. Alat yang digunakan hanya sebatas 3 buah congklak. Berdasarkan rasio jumlah anak bermain dalam kelompok dan alat permainan yang tidak sesuai, hal tersebut mengakibatkan terjadinya perebutan dan ketidak sabaran anak dalam menunggu temannya dalam menyelesaikan permainan. Namun demikian, peneliti telah membuat jadwal permainan, durasi permainan yang dilakukan 1 kelompok. Cara lain yang dilakukan yaitu dengan cara mengalihkan anak yang belum dapat giliran bermain dengan mengajak bermain ular naga. Namun nampaknya anak kurang berminat dan kurang mendapatkan respon bermain ular naga. Berdasarkan hasil penelitian ini, maka peneliti bertujuan pada uji coba selanjutnya peneliti tidak lagi menggunakan permainan ular naga. 


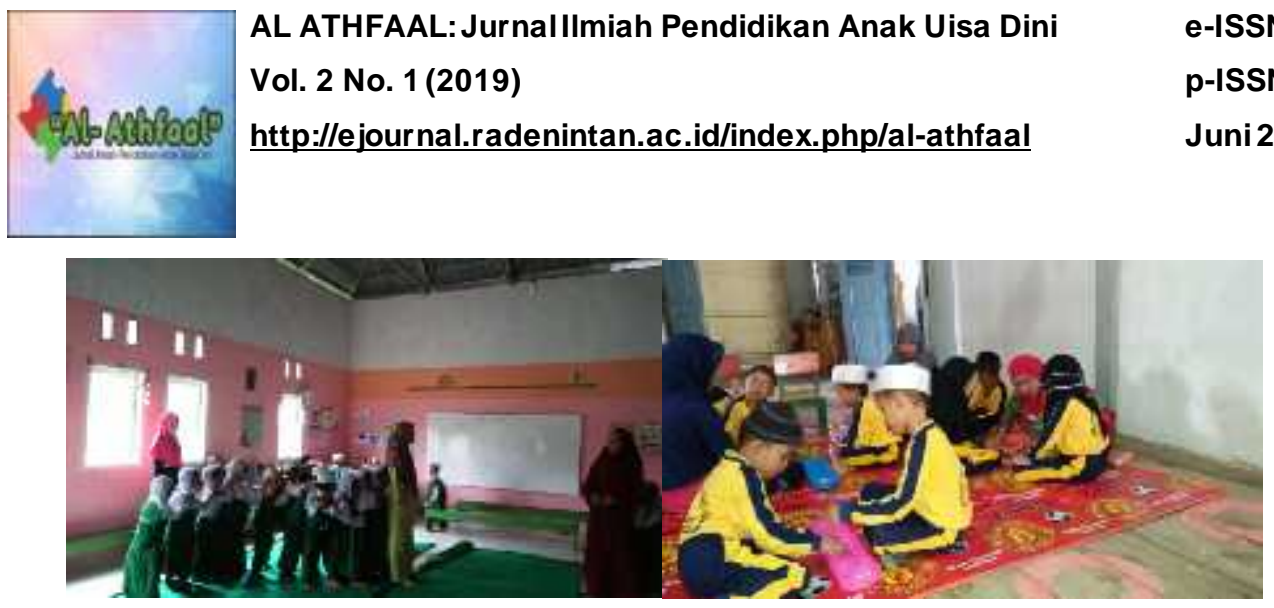

Gambar 1. Uji Coba Awal

\section{Perbaikan Awal}

Berdasarkan hasil pengamatan selama uji coba awal, maka selanjutnya peneliti melakukan revisi terhadap model permainan, yang mana permainan hanya difokuskan pada satu permainan yaitu permainan congklak saja. Revisi juga dilakukan khusus pada peraturan permainan yaitu pijakan saat bermain dan.kebebasan dalam memilih pasangan teman untuk bermain. Landasan teoritis model permainan tradisional ini tidak mengalami perubahan, sedangkan yang berubah adalah masalah limit waktu bermain yang awalnya 30 menit maka akan diubah menjadi 60 menit. Dan penambahan alat permainan yaitu congklak pada uji coba awal congklak yang digunakan sebagai media permainan hanya 3 buah, sehingga kurang efektif dikarenakan tidak bersesuain dengan rasio jumlah anak yang bermain. Pada uji coba selanjutnya, congklak sebagai media permainan ditambah menjadi 5.

\section{Uji Coba Lapangan}

Pada uji coba lapangan adalah uji coba lebih luas, model permainan dilakkukan di RA Nurul Islam Kelurahan Pasir Panjang Kecamatan Danau Teluk Jambi Kota Seberang pada tanggal 16, 17, 21, 27, dan 28 April 2018 dengan jumlah subjek penelitian sebanyak 10 anak. Durasi waktu dalam melakukan model permainan lebih lama dibandingkan dengan uji coba awal. Perpanjangan waktu dengan menambah 30 menit sehingga menjadi 60 menit, hal tersebut dengan pertimbangan bahwa anak usia 56 tahun adalah anak yang pada usianya suka dan senang bereksplorasi dan tidak pernah diam di tempat. Oleh karena itu dengan peraturan yang dibuat untuk disepakati, anakanak dalam rentang waktu yang telah ditetapkan harus menyelesaikan permainan tersebut. Dalam permainan tersebut dituntut untuk bertanggung jawab dalam 
menyelesaikan permainan, mengembalikan dan merapikan permainan, melatih mengendalikan diri, dan mentaati peraturan yang telah disepakati bersama.

Berdasarkan hasil pengamatan proses pembelajaran di RA Nurul Islam untuk menggunakan metode permainan dan alat permainan untuk mengembangkan aspek perkembangan anak. Melalui bermain dan alat permainan guru dapat mengenalkan konsep-konsep, seperti konsep mengenalkan warna, konsep jumlah, konsep bentuk dan bahkan memberi pemahaman tentang konsep kerjasama, berbicara dan memahami peraturan melalui bermain, terutama mengembangkan permainan tradisional.

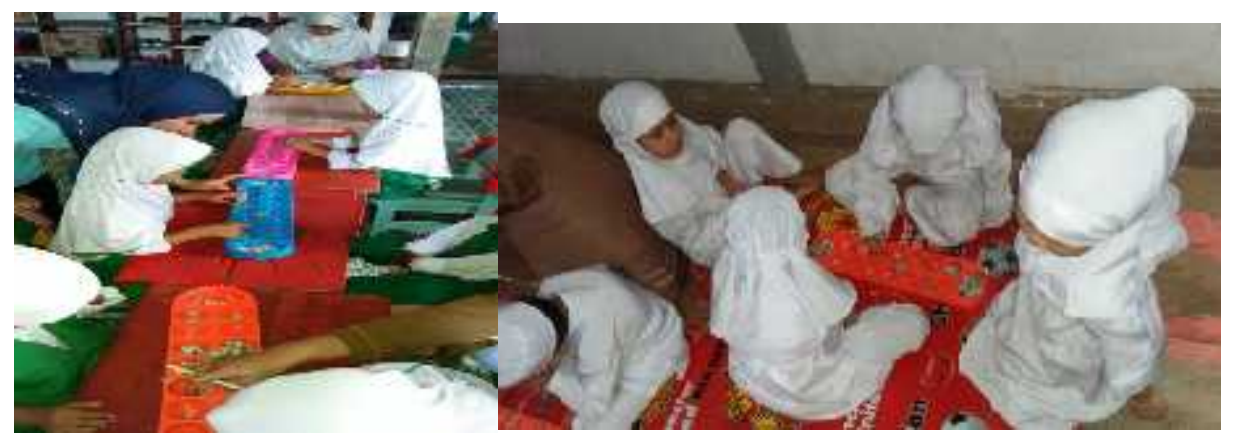

Gambar 2. Uji Coba Lapangan

\section{Validasi Model Permainan dan Instrumen}

Validasi model permainan dilakukan baik terhadap prosedur pelaksanaan dan kegunannya maupun instrumen yang digunakan. Dari hasil temuan selama uji coba dan berdasarkan hasil validasi ahli dinyatakan bahwa model permainan tradisional dapat dijadikan sebagai model permainan dalam pembelajaran anak usia dini yang dapat diterapkan sebagai model permainan area, dapat dimasukkan pada area sudut atau area bangunan, terutama model pembelajaran kelompok sesuai untuk menerapkan model permainan tradisional congklal ini. 


\section{Uji Efektifitas Model Permainan}

Uji efektifitas model permainan congklak dilakukan di RA Al-Jauharen Kelurahan Johor Kecamatan Pelayangan Jambi Kota Seberang pada tanggal 18 dan 19 Mei 2018. Hasil yang didapat berdasarkan pengematan yang dilakukan menunjukkan anak mampu beradaptasi, bersosialisasi dan dapat mengendalikan emosional mereka dengan baik.

Melalui pengalaman interaksional, anak belajar untuk mengendalikan diri, belajar memahami diri sendiri dan orang lain, juga lingkungan lain yang berbeda dengan dirinya. Sehingga anak tidak memaksa keinginanya kepada teman sebaya dan orang lain. Di samping itu juga dengan permainan tradisional anak belajar untuk bertanggung jawab menyelesaikan permainan dan belajar mengembalikan permainan dan merapikannya. Dan juga mengajarkan anak untuk sportif dalam permainan yaitu belajar menerima keunggulan teman dan belajar menerima kekalahan dirinya apabila kalah dalam permainan.

Oleh karena itu yang dapat diperoleh dari penerapan permainan tradisional congklak adalah nilai-nilai edukasi yang syarat dengan makna bagi perkembangan anak usia dini.

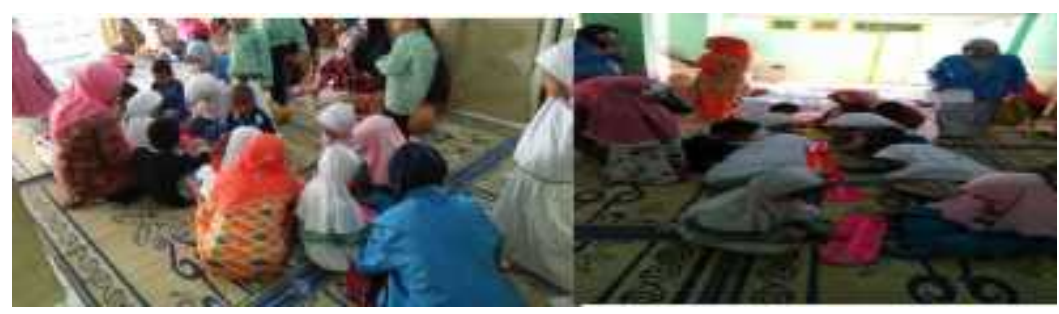

Gambar 3. Uji Efektivitas

\section{SIMPULAN DAN SARAN}

Berdasarkan penelitian yang telah dilakukan, maka penelitian ini meyimpulkan bahwa pengembangan model permainan tradisional menjadi permainan tradisional edukatif yang dapat meningkatkan kemampuan sosial emosional dan memberikan makna positif bagi anak usia dini. Makna porotof yang ditemukan yaitu terjalinnya silaturahmi melalui pengalaman interaksional dalam beradaptasi satu dengan yang lain yaitu interaksi antara anak dan anak, ataupun anak dan guru. Selama ini belum terpikirkan oleh guru bahwa melalui permainan tradisional terdapat nilai dan makna edukasi di dalamnya. Selain itu permainan tradisional dapat melatih emosional anak dengan melatih anak untuk bersabar menunggu giliran bermainnya dan juga melatih 


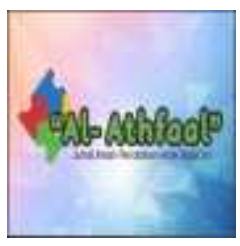

anak untuk mentaati peraturan. Melalui permainan tradisional, hal tersebut dapat mebawa anak larut dalam keasikan bermain yang melibatkan aspek emosional mereka yang tidak hanya hanyut dalam kesendirian. Dan dengan permainan tradisional kemampuan sosial emosional anak dapat ditingkatkan.

Berdasarkan kesimpulan di atas, salah satu saran yang dapat diberikan yaitu sebagai tenaga praktisi pendidikan anak usia dini harus mengkaji ulang dan cermat dalam menggunakan berbagai jenis permainan tradisional dalam mengembangkan bernagai aspek perkembangan anak untuk menjadikan permainan tradisional sebagai permainan yang memberikan nilai dan makna. Kemudian peran orang tua juga penting dalam mengenalkan anak permainan tradisional.

\section{DAFTAR PUSTAKA}

A. J., N., \& M., A. (2013). Dinamika Perkembangan Anak \& Remaja. Bandung: Refika Aditama.

Christie, J. F. (1990). How much time is needed for play? Young Children. 45.E. B., H. (1978). Child Development. Jakarta: Erlangga.

Hapidin, H., \& Yenina, Y. (2016). Pengembangan Model Permainan Tradisional Dalam Membangun Karakter Anak Usia Dini. Jurnal Pendidikan Usia Dini, 10(2), 201-212.

J, S. (2012). Life-Span development Edisi Ketigabelas Jilid 1. Jakarta: Erlangga.

Karyanti, K., \& Komarudin, K. (2017). Pengaruh model pembelajaran kumon terhadap pemahaman matematis ditinjau dari gaya kognitif peserta didik pada mata pelajaran matematika kelas viii smp negeri satu atap 4 pesawaran. Prosiding Seminar Nasional Matematika dan Pendidikan Matematika, 1, 89-94.

Munawaroh, H. (2017). Pengembangan Model Pembelajaran dengan Permainan Tradisional Engklek Sebagai Sarana Stimulasi Perkembangan Anak Usia Dini. Jurnal Obsesi: Jurnal Pendidikan Anak Usia Dini, 1(2), 86. https://doi.org/10.31004/obsesi.v1i2.19

Prisia Yudiwinata, H. (2014). Permainan tradisional dalam budaya dan perkembangan anak. Paradigma, 2(3). Diambil dari https://jurnalmahasiswa.unesa.ac.id/index.php/paradigma/article/view/9088 
Rodiawati, H., \& Komarudin. (2018). Pengembangan e-learning melalui modul interaktif. 16(2), 172-185.

Syaodih, E., \& Agustin. (2013). Penelitian Bidang Keilmuan: Penerapan Permainan Tradisional "Kaulinan Barudak" untuk Mengembangkan Nilai Karakter Anak. Bandung: UPI.

Widyawati, S. (2016). Pengaruh kemampuan koneksi matematis siswa terhadap prestasi belajar matematika ditinjau dari gaya belajar pada materi bangun ruang sisi datar siswa kelas ix smp di kota metro. Jurnal Iqra' : Kajian Ilmu Pendidikan, 1(1), 47-68. 